\title{
Pursuing Freedom, Making Strange: Pedagogical Considerations for Art as an Other
}

\author{
Lana Parker \\ York University
}

\begin{abstract}
This analysis addresses the ethical and epistemological considerations for using an arts-based pedagogy in the classroom as a means of disrupting dominant hegemonies and as a foundation for a more inclusive, robust democracy. The work advances two arguments. First, education must seek recourse for a renewed democracy by focussing on our ethical and political responsibilities in relation to the other. Second, art can serve to act as that other in unique and powerful ways in the classroom. I begin by proposing that an intersubjective relation is at the heart of both ethics and politics. I then consider how art can serve as an other in that relation. To conclude, I discuss the pedagogical implications for art as an other in pursuing freedom and advancing toward democracy.
\end{abstract}

Keywords: art; art pedagogy; ethics; democracy; other

Dr. Lana Parker is a Course Director at the Faculty of Education at York University, Toronto, Canada. She researches and writes about the complex intersections of literacy pedagogy, politics, and philosophy of education.

Email: laparker@edu.yorku.ca 
This study explores the possibilities for an education that forefronts the intersubjective relation as the heart of both ethics and politics, and that enriches learning through a considered approach to the arts. First, I argue that in the face of post-industrial liberalism, neoliberalism, and neoconservatism, education must seek recourse for a renewed democracy by focussing on our ethical and political responsibilities in relation to the other. I suggest that art, as an encountered sign, can serve as an other in the classroom. The last half of this analysis considers two possibilities for pedagogy: art as a way of pursuing freedom and art as a way to move toward a deeper, more responsive democracy.

\section{The Significance of the Other}

In seeking to disrupt dominant hegemonies and in moving toward a more just and inclusive democracy, this work aims to establish an intersubjective relationship with the other as requisite to ethics and politics. To elaborate on the significance of the other for ethics and politics, it is useful to contemplate the work of Levinas $(1989,2011)$ and Arendt (1998). Their work offers possible consideration for how (and why) the other might be established as a primary point of departure in our search for meaning-making that is simultaneously inclusive and disruptive.

\section{Levinas: Listening, Responsibility, Wisdom, and Freedom}

Levinas (1989) proposes the conditions for an ethics that is rooted in our inherent responsibility for the other. Each person assumes a pre-ontological responsibility for an "other" whose place and space they inhabit. Levinas (1989) notes, "one has to respond to one's right to be, not by referring to some abstract and anonymous law, or judicial entity, but because of one's fear for the Other" (p. 82). A person meets this responsibility through an interaction with the other in which the self (I) becomes a listener who is vulnerable to the other; this other speaks to me and calls me into question. In this interaction, where I am the listener the other becomes my teacher, I listen with the aim, not of possessing a complete knowledge of the other, but with the goal of breaking apart my own incomplete understandings of the world. I resist complete knowledge, the pretence of full understanding, which Levinas (1989) terms the bonne conscience, by seeking the uncertainty of the "mauvaise conscience" (p. 82) instead.

The distinction between the bonne and mauvaise conscience can be articulated as the difference between knowledge and wisdom. For Levinas, the bonne conscience is synonymous with Western epistemologies that prioritize the mastery of "accepted doctrine, teachings, [and] sciences" (Levinas, 1989, p. 77). Knowledge, independent of the other, is self-contained and untroubled, and "to know amounts to grasping being out of nothing or reducing it to nothing, removing from it its alterity" (Levinas, 2011, p. 44). The mauvaise conscience is, on the other hand, fragile. It is disrupted by our interactions with the other. Listening to the other troubles the mauvaise conscience, breaks through our sense of self and surety. Wisdom, for Levinas, emerges only through this intersubjective relation with the other.

This reading of ethics rejects conventional Western philosophical tradition, which correlates knowledge and being (Eppert, 2000) and has direct implications for learning. Learning for knowledge is "linear, cumulative, and progressive and leads to mastery" (van Alphen, 2005, p. 186); it unburdens the self from the responsibility to listen to the other and offers, in lieu of the 
work of listening, certainty of what is and what will be. Wisdom, on the other hand, is tenuous; it emerges only through an interaction with the other in which we are forced to recognise the limits of knowing.

It is through this act of listening that the self also finds freedom. Freedom is produced through the act of listening because the possibilities for wisdom are infinite. Each interaction with the other produces wisdom. And yet, as listeners in this ethical exchange, we will never be able to know everything about the other; we will not be able to claim their alterity. There is always more to learn. Listening to the other as an ethical imperative advances a "freedom [that] consists in knowing that freedom is in peril" (Levinas, 2011, p. 35). This uneasy freedom is not a freedom from rules and obligations, but a freedom to submit to the ongoing work of listening and responding. In this way, freedom and wisdom emerge from the same space: from the demand of responsibility born of existence; from the call to listen; and from the uncertainty summoned forth in the shaky spaces between self and other.

\section{Arendt: Politics, Natality, and the Common World}

If the other is central to ethics, then it must also be the foundation for action, or politics. In The Human Condition, Arendt (1998) observes "no human life, not even the life of the hermit in nature's wilderness, is possible without a world which directly or indirectly testifies to the presence of other human beings" (p. 22). She goes on to describe a political process that necessitates the presence of others, is rooted in the act of speaking, and resists conformity. This reading of politics relies not only on the interaction between self and other(s), but also on the fundamental assertion that everyone brings something new into the world. Arendt (1998) terms this newness and possibility "natality," indicating that each person has the potential to enact change through participation in the polis and through a contribution to the common world. The concept of natality ties politics to listening, and to Levinas' distinction between knowledge and wisdom, because the newness of the other is inherently unknowable. Natality endorses the suggestion that the alterity of the other lies beyond the grasp of knowledge.

Another aspect of Arendtian politics that is useful to the discussion of the other, and which is particularly relevant to a question of how educators might consider art in the classroom, is her emphasis on the common world. The common world is the shared space where democracy happens and it implies both a historicity and futurity. Arendt (1998) suggests: "if the world is to contain a public space, it cannot be erected for one generation and planned for the living only; it must transcend the life-span of mortal men" (p. 55). In the common world, one's actions are imbued with a new purpose: what one builds in a lifetime should not merely advance personal wealth, but ought to surpass one's own existence and become part of a larger world. Individual acts of interruption toward change become expressions of self that give meaning to a person's existence through hope, through participation in a common world, and through the creation of something that speaks beyond one's own sphere of need. It is precisely for this reason that the arts are important. As Arendt (1998) articulates, the arts interrupt in the moment of creation, but they also abide:

If the animal laborans needs the help of homo faber to ease his labor and remove his pain, and if mortals need his help to erect a home on earth, acting and speaking men need the 
help of homo faber in his highest capacity, that is, the help of the artist, of poets and historiographers, of monument-builders or writers, because without them the only product of their activity, the story they enact and tell, would not survive at all. (p. 73)

By both interrupting and abiding, the arts serve a unique role in the common world. The common world becomes a context for emergent gestures toward democracy, but also a space where the traces of gestures past may reappear, to be studied and questioned, and to provoke further interruption.

\section{Coming Together: Intersubjectivity as the Basis for Ethics and Politics}

Bringing together Levinas and Arendt does not signify that their thinking can be wholly reconciled. Instead, this discussion provides the basis for intersubjectivity as a necessary condition for ethics and politics. The ethical relation furnishes the conditions for democracy that, rather than being delineated as a deliberative process toward overcoming conflict or as an ethics that can be structured into law and institution, is more about furnishing the conditions for an "interruptive moment to the otherwise rational decision-making, planning, and prioritizing that goes on in the name of democratic politics" (Todd \& Säström, 2008, p. 7).

This framework is a coming together in layers: of Levinas with Arendt, of the ethical and the political, and of the self and other. It builds on the suggestion that intersubjectivity "is the bridge between Arendt's notion of the political as rooted in plurality and Levinas' ethics of alterity" (Topolski, 2008, para. 1) and it forefronts the intersubjective relation as necessary for responsibility, wisdom, freedom, and political action.

\section{Why Art as Other?}

Art, defined broadly here as engagements with visual art, music, film and theatre, dance, and literature, offers several possibilities for the intersubjective relation and for political action. Before proceeding with the argument for art as an other, it is relevant to note that Levinas (1989, 1991, 1996, 2011) presented ambivalence about arts' capacity to function as an other in the intersubjective experience. While it is beyond the scope of this work to address this ambivalence, it is helpful to note that a body of scholarship exists interrogating Levinas' complex writing on the subject and developing ways to theorize art as other (Eppert, 2008; Kearney, 1995, 1999; Kenaan, 2011; Robbins, 1999, 2005; Staehler, 2010; Zhao, 2014).

Adams (2002) notes that art can: express the ideas and emotions of an individual or a group; become the voice of movements and protests; deepen commitment to a movement; reach a broader and more varied audience; have effects on broader culture; and evoke emotion. The connection between art and affect is important. In her work on art and trauma, Bennett (2005) uses a Deleuzian understanding of art as an "encountered sign" (Deleuze, as cited in Bennett, 2005, p. 7) to suggest that art is first received not through recognition or cognition, but through how it is felt. Deleuze (2000) notes that "thought is nothing without something that forces and does violence to it. More important than thought is 'what leads to thought'; more important than the philosopher is the poet" (p. 95). In this way, art becomes an impetus for thought and for listening. The affective operations of art are less about form and substance, and more about bringing the viewer into a receptive state for thinking, listening, and responding. 
A second consideration is that art makes space for reflection and responsiveness without the pretence of truth. Deleuze (2000) contends:

the truths that intelligence grasps directly in the open light of day have something less profound, less necessary about them than those that life has communicated to us in spite of ourselves in an impression, a material impression because it has reached us through our senses.... (pp. 95-96)

Art, when seen here as a sensory impression, becomes a profound mode of communicating because it not only contains some substance and form that require thought, but also because, even more primitively, it engenders an affective response. This is perhaps why it is easier to turn away from news items about genocide than it is to watch documentaries or to view art or to listen to music expressing that particular trauma. The media pretends at the "open light of day" and is viewed with jaded cynicism. Whereas media feigns the offer of truth without taint, reality without the veneer of hegemony, art is honest in its innate positionality.

The fact that art works as an encountered sign, is felt more than thought, leaves us potentially more open and more receptive than we might otherwise be to the ruptures of interaction with the other. Art renders us more receptive to "listening" and to wisdom through our affective response. And while it may not evoke the same immediacy and power of a human interaction, art brings the voice of the other into spaces that the human other cannot attend (including the confines of the classroom). The connection here, made between art and affect and the orientation for an encounter with the other, is important because it advances the idea that art can perform an ethicopolitical function and that it can be especially effective because it is felt rather than understood. The linkages between art, affect, and the ethicopolitical are also significant because they invite a sense of futurity that breaks from the moment of the present and toward something that may be. Once again, art draws on affect by refraining from offering "a reassuring mirror reflection of a subjectivity already in place" (O'Sullivan, 2010, p. 200), art liberates us from the tyranny of a future defined by the present and leaves us uncertain. It is a sense of uncertainty that evokes a sense of the possible. Put another way, it is an uncertainty that emanates the fragile light of hope.

\section{Creating the Conditions for Art as Other in the Classroom}

So what does an other-centred ethics and politics mean for an arts-based pedagogy? If the arts are a voice of the other, then they ought to be meaningfully integrated, through both creation and analysis, as modalities of literacy to build meaning and interrogate norms across curriculum (for more on this see Albers \& Sanders, 2010; Apple, 2006; Cowan \& Albers, 2006; Flood, Heath, \& Lapp, 2015; Lynch, 2007; Russell \& Zembylas, 2007; Zhao, 2014). And yet, a focus in recent years on literacy and numeracy, on standardized testing, and on achievement (high grades, good jobs) has diminished the scope and depth of art teaching (Zhao, 2014).

For the remainder of this analysis, I advocate for a pedagogy that advances toward goals of freedom and democracy by upholding the meaningfulness and importance of art in the classroom. I examine Greene's $(1973,1994,1995)$ thinking about art to articulate the goals of the pedagogy and a range of scholars to develop particular strategies in support of the pedagogy. In this way, I illustrate how art can open classrooms to the plurality and possibilities of the other by making 
space for the pursuit of freedom and by "making [the world] strange" (Greene, 1994). I also offer strategies for educators to consider in creating the conditions for art as an other.

\section{Art and the Pursuit of Freedom}

Art exists beyond the confines of knowledge and the bonne conscience. There is no certainty or pretence of truth in art because "art cannot be known in the same way we know 1+1=2" (Zhao, 2014 , p. 247). Art provokes the mauvaise conscience by confronting us with the other in a way that preserves the other's alterity and draws us closer to wisdom. It exceeds us in much the same way as we are exceeded in a face to face with the other who we cannot completely understand or claim. This is where we find freedom.

Greene (1994) describes this surplus by noting, "no accounting, disciplinary or otherwise, can ever be finished or complete. There is always more. There is always possibility. And this is where the space opens for the pursuit of freedom" (p. 128). Greene's (1994) chapter in The Dialectic of Freedom, titled "Multiplicities, Pluralities, and a Common World" brings together the idea of multiplicity with the potential for the common world. In it, Greene suggests that in listening, attending to voices from an other, we open ourselves to possibilities for freedom. Using MerleauPonty, she notes that, "the freedom to be sought is inextricably meshed with responsibility and obligation" (Greene, 1994, p. 100). She also determines that art is one of the most powerful tools for pursuing that freedom through listening and exploring multiplicities:

art objects - not only literary texts, but music, painting, dance... have the capacity, when authentically attended to, to enable persons to hear and to see what they would not ordinarily hear and see, to offer visions of consonance and dissonance that are unfamiliar and indeed abnormal, to disclose the incomplete profiles of the world. (p. 129)

To do this requires a careful attention to pedagogy that does not foreclose alterity and presume knowledge. It requires that educators create the conditions for the study and creation of art in ways that pursue freedom through listening, through responsibility. Three strategies for teaching toward freedom are suggested below.

Pursuing freedom through questions for wisdom. One strategy is to make space for a particular kind of listening that moves away from the boundaries of a knowledge discourse to the possibilities of an interpretive or interruptive inquiry. Todd (2003) provides a way into a space of inquiry that integrates Levinasian listening with education. She suggests that this type of listening should form the foundation for a pedagogy rooted in social justice. Todd (2003) notes, "underlying each [student's] responses is a certain quality of attentiveness in the listening of those stories; and it is this quality that seems to me to be important for considering ethical relations across difference, and ultimately for relations of justice" (p. 405). Here, the author is alluding to the particular orientation toward the other that Levinasian listening requires. It is a willingness to receive without the pretence of ownership. Todd (2003) elaborates this nuance: "someone who might deeply identify with another who may be suffering ... may not be listening and attending fully to the difference that marks the other's experience as unique and distinct from one's own" (p. 405). As teachers offer students multiple voices through exposure to art, they must also encourage a certain orientation that refrains from presenting the other as an anecdote of history or a fact to be seized 
and memorised. Teachers can do this by disclosing the limits of their own wisdom and by presenting the other as an indomitable voice, whose experience can affect us, but whom we may never fully claim. Teachers can, as Todd (2003) does, ask questions that draw attention away from knowledge and rely on the shaky ground of listening for wisdom: "What is it that we listen to when we listen? How does listening contribute to establishing a specifically ethical attentiveness to difference? And, how might listening open up the possibility for a just response?" (p. 405). These questions help us to pursue freedom by exposing the tenuous scaffolds supporting what we construe as factual curriculum; they oblige us to turn our search for freedom away from a freedom from commitments, toward a freedom to respond.

Pursuing freedom through relation. A second strategy to make space for freedom is to move away from the study or creation of art that exemplifies outcome over process or meaning. Simon's (2005) work on memory and history, which does not insist on conformity but relies on plurality, helps articulate a way to teach art that does not inculcate. Simon (2005) contends, "the practice of a transactive public memory evokes a persistent sense-not of belonging but of being in relation to, of being claimed in relation to the experiences of others" ( $p .89$, emphasis in original). The lack of belonging to a group means that one is not constrained by the boundaries of a particular group or set of rules. Using a relational approach, students are not bound to produce a specific outcome with their art nor are they compelled to identify the "right" meaning or message. Instead, educators can help students to explore art as a means of expression and as a voice of the other without insisting on replication or on one right way to interpret the work. Arts pedagogy shifts away from performance of perfection, and toward the creation of a relationship between students and the possibilities for art as inquiry and response. It is an approach that may render the learner more willing to question the role, purpose, and function of art from the past; also, more importantly, because the students are not forced into belonging or conforming, they may be more prepared to create art in response to their own socio-political context.

Pursuing freedom through transactional memory. A third strategy is to learn to work with diverse, historical examples of art without losing the ability to look forward into the possibilities for art as interruption. A significant amount of education, especially art education, is framed using tools and examples from the past referencing a traditional canon of works and principles. An educator must learn to interact with this form of art without foreclosing possibility for newness and natality. Simon (2005) assists with this reorientation from study of the past to becoming open to the possibilities for the future. He suggests collective public memory is not based on a stagnant knowledge set, but is instead concerned with creating a series of transactions that shape who we are and how we think by enacting a claim upon us. Simon (2005) calls for pedagogy that opens our historical consciousness to revision through an ongoing exposure to narratives that exceed our current impression or understanding. He notes:

On such terms, a transactive memory has the potential to expand that ensemble of people who count for us, who we encounter, not merely as strangers (perhaps deserving pity and compassion, but in the end having little or nothing to do with us), but as 'teachers,' people who in telling their stories change our own. (Simon, 2005, pp. 88-89) 
Because curriculum for the arts almost always draws upon the art's history and principles from the past as its substantive content, educators must consider how to work with these tools in a manner that does not become rigid or certain. The approach is also relevant when teaching about historical context in other subject areas, since it calls historical consciousness into a space of ongoing revision. The pedagogy of transactional memory helps re-orient the learner from a disposition of passivity and indulgence (or mere appreciation in the case of arts pedagogy) to a state of personal responsibility and self-reflection.

Central to this pedagogy is the decision to work with art so that it appears not superficially as a manifestation of elements and principles that have been collated into a disciplinary method, but so that it troubles the learner's perceptions of what art can achieve and how art's purpose can diverge from conventionally held beliefs. To this end, educators should reference more than traditional canon, introducing art into the classroom that draws attention to the voices and authentic narratives of the marginalised, the hidden, and the invisible. These examples of art should not confirm students' own stories, or be used merely as windows into a discussion of principles and form. Instead, art should tell the stories of both those who are in the classroom and have no voice in traditional curricular space, and those who are not represented in the classroom but who might be considered in discussions forging a common world.

\section{"Making Strange": The Promise of Art and the Possibility for Democracy}

Now that the groundwork has been laid for the pursuit of freedom, the question becomes what do we, as a society, hope to move toward in our gestures for freedom? In reply, I draw a connection between an other-centred ethics and politics, and the potential for art as a move toward democracy. As I have previously argued, art is a powerful conduit to open students to a sense of the possible, because it is both accessible and affectively evocative. While it is difficult to always model the process of democracy within a school setting with its inherent contexts of power, the creation and analysis of art provide a window to respect for the other and hope for the future.

Greene $(1973,1994,1995)$ describes this process and the utility of art for opening a classroom up to the world. In particular, she provides for a way of "making strange" (Greene, 1994, p. 122) the world that students and teachers share by shifting perspectives, interrogating meaning, questioning assumptions, and defamiliarizing the familiar. Greene's approach for teaching lifts the terrible burden of conformity and obedience from the shoulders of students, and gives them license to engage, with respect and humility, the vast possibilities of the other. The pedagogy she develops mimics the orientation to the other that is needed to enact ethical politics and helps students begin to see art as a potential tool to explore democracy. While the previous strategies help move classrooms toward listening as responsibility, the next three can be thought of as strategies that move toward complex engagements with democracy. The pedagogy: suggests that art can render the world we share strange (Greene, 1994); is situated against the concept of the pre-formed citizen (Biesta, 2011); and relies on complex processes of witnessing and questioning (Maclear, 1999, 2003).

Making "art" strange. One strategy to move toward democracy is to show students that there is room, even within established systems, for something new, something strange. The arts 
may be integrated into the classroom as an innovation or as a means to re-examine something familiar. Teachers can talk to students about how artists have deconstructed life experiences by first disassembling, and often times discarding, the "communal symbolism that made the visual arts a unifying force in earlier times" (Greene, 1973, p. 12). They can discuss how artists have pushed against the boundaries of the rules of their medium in the ongoing pursuit of making meaning and of resisting hegemonies. By working against convention, some artists have begun "tampering with inherited conventions, questioning the very idea of art" in order to force people to "examine [their] own preconceptions and expectations" (Greene, 1973, p. 12). This marks a purposeful shift away from standards and skill, and it mirrors the shift away from absolute knowledge that is required to begin with the break from the bonne conscience. Teachers can share examples of artists, writers, musicians, filmmakers and dancers who, by rejecting the historical parameters of connoisseurship, are offering people a chance, through art, of exploring the openness, tenuousness, and possibility of meaning. It is for this reason that the arts provide a unique opportunity to teachers and students, not only as a means of re-seeing the world for themselves, but also to introduce the complexity of meaning into the curriculum.

Making "the citizen" strange. Another pedagogic move toward democracy can be realized through explorations of art that challenge the narrative of the "good citizen." Biesta (2011) clarifies that the concept of educating for democracy, manifesting as it often does through character education, is incompatible with an ethics and politics based on the other. This is because character education suggests that the ideal characteristics for a democratic citizen can be inculcated through explicit instruction of values; it proposes that what is best for democracy is what is, or what has been, rather than what could be. Biesta (2011) notes that notions of the good citizen and character education are founded in knowledge claims that reflect what a society thinks they collectively know and believe to be correct in the present. These knowledge claims include "knowledge about what a good citizen is; knowledge about what a good citizen needs to learn; and knowledge about how individuals can learn to become good citizens" (Biesta, 2011, p. 142). The danger, as Biesta and others (Mouffe, 2005; Todd \& Säström, 2008) have observed, is that any type of democracy formed on the basis of knowledge claims pins down its citizens into one mode of doing, thinking, and speaking. It automatically asserts the primacy of a single ontology — of, as Simon (2005) suggests, belonging. It bars from the conversation the possibility of the other. The multiplicity of perspectives that Mouffe (2005) refers to as multipolarity does not form a substantive element of learning.

Biesta (2011) argues against the pre-formed citizen and toward the "ignorant citizen" using a pedagogy that discards claims of certainty and knowledge. This pedagogy works directly with the concept of fallibility and suggests that humility is the characteristic most needed to really learn from the other. In this vein, Todd and Säström (2008) suggest that the most important aspect of education for democracy is telling students "to come to an acknowledgement of their implication in creating - and sustaining - exclusionary forms of belonging in holding certain points of view collectively" (In Education for a Democratic Promise section, para. 3). Students are not expected to enter into the dominant discourse, accepting it as the one true path to democracy. Instead, their study of society, economics, and politics, provides possible points of connection to students who are seeking to understand their own relationship with the common world. To this end, teachers 
must integrate the arts across subject areas as both a resource and as modalities of expression. They can bring examples of art into the classroom that introduce students to artists who disrupt hegemonic norms and resist tyranny through the voice their art has lent them. They can also provide opportunities through various curricula for students to create responses to issues of inequality in their communities using the arts as a voice. In this way, students can begin to identify the arts as a means of voicing resistance, participating in and influencing democracy, and constructing possibilities for new expressions of citizenry.

Making "listening" strange. A further pedagogic strategy for making strange is to move from listening for wisdom to a kind of parallax listening that brings the self/other interaction into the context of sociality and democracy. As Greene (1973) notes, art can bring diverse modes of analysis into the classroom:

Those who read or look or listen attentively can create new orders within themselves.

Doing so, they are likely to discover new meanings, unsuspected angles of vision; they may discover original perceptions of what it is like to be alive, "themes of relevance" against which students can pose worthwhile questions. (p. 16)

Learning to question and to receive are central to an arts-based pedagogy grounded in an ethics and politics based on the other. In a previous section, "Pursuing freedom through questions for wisdom," I advocated for a type of reflective questioning that seeks wisdom by making space for plurality. In this section, I suggest that this strategy can be extended into parallax questioning, a term I adapt from Maclear (1999, 2003) who develops it as a way of engaging with art.

Maclear's $(1999,2003)$ work on witnessing, historicity, and art offers yet another way of making what exists strange in an effort to move toward the possibilities of democracy and justice. There are resonances between Maclear's (1999) and Greene's (1994) writing on art, as Maclear (1999) contends that art "may open up new sites of possibility by providing opportunities to see and hear what has become familiar differently" (p. 86). Maclear (2003) advances a parallax approach as a way of double questioning that makes space between what is and what is not represented. The first type of question, the "corrective" question, aims to deconstruct what is represented by asking "what counts as evidence" (Maclear, 1999, p. 86). The second type of question, the "contemplative" question, produces space to examine what our assumptions are in response to the work. Here I suggest a minor revision in the nomenclature of the questions that I believe offers nuance for art pedagogy. In lieu of being corrective, I offer constitutive questions to help students locate art's relationship to the world. Contemplative questions, renamed intercessive questions to reflect the navigation of space between self and other, help students relate the art to their own lives. Constitutive questions ask teachers and students to look closely at the social influences that informed the work: What do we see? Why has it been produced? How has society determined that this work counts (or does not count)? Intercessive questions ask teachers and students to explore their personal response: What do I feel? What experiences and biases do I bring to this work? Why do I perceive the work this way? Is there another way of responding? Taken together, this double questioning serves to destabilize knowledge and certainty. It makes room for the other not only through study of art, but also through an examination of the process of how we engage with the art and how that art exists in the world. Because this double questioning interrogates art/world and art/self connections, it both challenges norms and builds pathways for 
connection. It makes space for political action without collapsing each student's uncontainable alterity.

\section{Concluding Thoughts}

We are bound by our skins. These bodies we inhabit present our first limit, the first press of horizon against other, the world of inside and outside. If we present students with a world as it isa collection of facts, a reified knowledge - we serve only to reinforce the boundaries of their world: what is within and what is without. If we adhere to a curriculum of knowledge, especially knowledge as it is presented and defined by dominant hegemony, we obscure the possibilities for diversity and change. Art offers a way to listen to the other, to broaden students' exposure to diverse perspectives, and to provoke uncertainty. Art inverts the thematization of the world: instead of saying to students "here is the world, make space for yourselves in it," art suggests that not all is yet known of the world, that new spaces are continuously carved and forged. Art helps educators construct the world in all its fragility, suggesting that there is something beautiful in incompleteness. It forefronts the uneasy motion between listener and speaker, self and other, as the essential tension, as the responsibility that begets freedom. 


\section{References}

Adams, J. (2002). Art in social movements: Shantytown women's protest in Pinochet's Chile. Sociological Forum, 17(1), 21-56.

Albers, P., \& Sanders, J. (Eds.). (2010). Literacies, the arts, and multimodality. Urbana, IL: National Council of Teachers of English.

Apple, M. P. (2006). Arts integration across the curriculum. Leadership, 36(2), 14-17.

Arendt, H. (1998). The human condition. Chicago, IL: Chicago University.

Bennett, J. (2005). Empathic vision: Affect, trauma, and contemporary art. Stanford, CA: Stanford University Press.

Biesta, G. (2011). The ignorant citizen: Mouffe, Rancière, and the subject of democratic education. Studies in Philosophy and Education, 30(2), 141-153.

Cowan, K., \& Albers, P. (2006). Semiotic representations: Building complex literacy practices through the arts. The Reading Teacher, 60(2), 124-137.

Deleuze, G. (2000). Proust and signs: The complete text. Minneapolis, MN: University of Minnesota Press.

Eppert, C. (2000). Relearning questions: Responding to the ethical address of the past and present in others. In R.I. Simon, S. Rosenberg, \& C. Eppert (Eds.), Between hope and despair: Pedagogy and the representation of historical trauma (pp. 213-230). New York, NY: Rowman \& Littlefield.

Eppert, C. (2008). Emmanuel Levinas, literary engagement, and literature education. In D. EgéaKuehne (Ed.), Levinas and education: At the intersection of faith and reason (pp. 67-84). New York, NY: Routledge.

Flood, J., Heath, S. B., \& Lapp, D. (2015). Handbook of research on teaching literacy through the communicative and visual arts, volume II: A project of the International Reading Association. New York, NY: Routledge.

Greene, M. (1973). Teacher as stranger: Educational philosophy for the modern age. Belmont, CA: Wadsworth.

Greene, M. (1994). The dialectic of freedom. New York, NY: Teachers College Press.

Greene, M. (1995). Releasing the imagination: Essays on education, the arts, and social change. San Francisco, CA: Josey-Bass.

Kearney, R. (1995). Poetics of modernity: Toward a hermeneutic imagination. New York, NY: Humanity Books.

Kearney, R. (1999). The crisis of the image: Levinas's ethical response. In G. B. Madison \& M. Fairbairn (Eds.), The ethics of postmodernity: Current trends in continental thought (pp. 12-23), Evanston, IL: Northwestern University.

Kenaan, H. (2011). Facing images: After Levinas. Angelaki: Journal of the Theoretical Humanities, 16(1), 143-159.

Levinas, E. (1989). The Levinas reader. Oxford, UK: Blackwell.

Levinas, E. (1991). Jean Atlan et la tension de l'art. In C. Chálier \& M. Abensour (Eds.), Cahier de l'herne: Emmanuel Levinas (pp. 509-510). Paris, FR: Herne.

Levinas, E. (1996). Paul Celan: From being to the Other. In Proper names (M.B. Smith, trans) (pp. 40-46). Stanford, CA: Stanford University Press.

Levinas, E. (2011). Totality and infinity: An essay on exteriority. Pittsburgh, PA: Duquesne University Press. 
Lynch, P. (2007). Making meaning many ways: An exploratory look at integrating the arts with classroom curriculum. Art Education, 60(4), 33-38.

Maclear, K. (1999). Beclouded visions: Hiroshima-Nagasaki and the art of witness. New York, NY: SUNY Press.

Maclear, K. (2003). The limits of vision: Hiroshima Mon Amour and the subversion of representation. In A. Douglass \& T. A. Vogler (Eds.), Witness and memory: The discourse of trauma (pp. 233-248). New York, NY: Routledge.

Mouffe, C. (2005). Cosmopolitics or multipolarity? Redescriptions: Political Thought, Conceptual History and Feminist Theory, 9(1), 15-26.

O'Sullivan, S. (2010). From aesthetics to the abstract machine: Deleuze, Guattari and contemporary art practice. In S. Zepke \& S. O'Sullivan (Eds.), Deleuze and contemporary art (pp. 189-207). Edinburgh, UK: Edinburgh University Press.

Robbins, J. (1999). Altered reading: Levinas and literature. Chicago, IL: University of Chicago Press.

Robbins, J. (2005). Aesthetic totality and ethical infinity: Levinas on art. In C. E. Katz (Ed.), Emmanuel Levinas: Critical assessments of leading philosophers (pp. 356-368). New York, NY: Routledge.

Russell, J., \& Zembylas, M. (2007). Arts integration in the curriculum: A review of research and implications for teaching and learning. International Handbook of Research in Arts Education, 16, 287-312.

Simon, R. I. (2005). The touch of the past: Remembrance, learning and ethics. New York, NY: Palgrave MacMillan.

Staehler, T. (2010). Images and shadows: Levinas and the ambiguity of the aesthetic. Estetika: The Central European Journal of Aesthetics, 2, 123-143.

Todd, S. (2003). Listening as attending to the "echo of the otherwise": On suffering, justice, and education. In S. Fletcher (Ed.), Philosophy of education yearbook 2002 (pp. 405-412). Urbana, IL: Philosophy of Education Society.

Todd, S., \& Säström, C.A. (2008). Democracy, education and conflict: Rethinking respect and the place of the ethical. Journal of Educational Controversy, 3(1). Retrieved from http://www.wce.wwu.edu/Resources/CEP/eJournal/v003n001/a012.shtml

Topoloski, A. (2008). In search of a political ethics of intersubjectivity: Between Hannah Arendt, Emmanuel Levinas and the Judaic. HannaArendt.net: Journal for Political Thinking, 4(1). Retrieved from http://www.hannaharendt.net/index.php/han/article/view/137/240

van Alphen, E. (2005). Art in mind: How contemporary images shape thought. Chicago, IL: University of Chicago Press.

Zhao, G. (2014). Art as alterity in education. Educational Theory, 64(3), 245-259. 